\title{
PENGEMBANGAN MEDIA PEMBELAJARAN VISUAL BAGI PEBELAJAR BIPA PEMULA DI UNDIKSHA
}

\author{
Ni Made Candra Puspita Lestari ${ }^{1}$, I Made Sutama², I Dewa Gede Budi Utama ${ }^{3}$ \\ Program Studi Pendidikan Bahasa dan Sastra Indonesia \\ Universitas Pendidikan Ganesha \\ Singaraja, Indonesia \\ e-mail: candrapuspitalestari@gmail.com, imadesutamaubd@gmail.com, \\ idgbudiutama@gmail.com
}

\begin{abstract}
ABSTRAK
Penelitian ini bertujuan untuk (1) menjabarkan desain pengembangan media pembelajaran visual bagi pebelajar BIPA pemula, (2) menguji validitas hasil pengembangan media pembelajaran visual, dan (3) mengetahui respon pebelajar BIPA terhadap media pembelajaran yang digunakan. Penelitian ini menggunakan rancangan penelitian pengembangan (Research and Development), dan menggunakan model pengembangan ADDIE. Subjek dalam penelitian ini adalah siswa BIPA tingkat pemula di Undiksha. Objek penelitian adalah media pembelajaran flashcard. Metode yang digunakan untuk mengumpulkan data adalah metode pencatatan dokumen, wawancara, dan angket. Untuk menganalisis data hasil penelitian, dalam penelitian ini menggunakan metode analisis data yaitu, analisis deskriptif kuantitatif dan deskriptif kualitatif. Hasil penelitian ini menunjukkan bahwa: (1) desain pengembangan media pembelajaran flashcard sesuai dengan prosedur dan prinsip-prinsip media pembelajaran dan telah dikembangkan dengan model pengembangan ADDIE. (2) Hasil uji validitas ahli media pembelajaran menunjukkan bahwa media pembelajaran flashcard layak untuk dikembangkan dan digunakan dalam pembelajaran BIPA. (3) Respon peserta didik BIPA di Undiksha terhadap media pembelajaran flashcard mendapat kategori respon positif dengan rata-rata persentase $85,65 \%$.
\end{abstract}

Kata kunci: BIPA, media pembelajaran, flashcard

\section{ABSTRACT}

This research aims to (1) explain the design of visual learning media development for BIPA learners, (2) examine the validity of visual learning media development result, and (3) investigate the BIPA learners' reponses toward the learning media. This research used Research and Development design, and ADDIE model. The subject of this research was BIPA learners in the beginner level of UNDIKSHA. The object was learning media in form of flashcard. The method used to collect data was documentation, interview, and questionnaire. In analyzing the data, the researcher used descriptive quantitative and descriptive qualitative method. The result of this research shows that (1) the design of flashcard learning media development is in line with the procedures and basic of learning media, and developed by following ADDIE model. (2) The result of expert judgments shows that the flashcard learning media is proper to be developed and used in BIPA learning. (3) The UNDIKSHA BIPA learners' responses toward the learning media shows positive responses with average percentage $85.65 \%$. 
Keywords: BIPA, visual learning, flashcard

\section{PENDAHULUAN}

Pembelajaran BIPA saat ini mulai berkembang pesat. Perkembangan itu belum ditunjang dengan adanya bahan ajar, dan media pembelajaran yang memadai. Pembelajaran BIPA memiliki karakteristik yang berbeda dengan pembelajaran bahasa Indonesia untuk penutur asli. Perbedaan tersebut terjadi karena (a) pelajar BIPA pada umumnya telah memiliki jangkauan dan target hasil pembelajaran secara tegas, (b) dilihat dari tingkat pendidikannya, pada umumnya pelajar BIPA adalah orang-orang terpelajar, (c) para pelajar BIPA memiliki gaya belajar yang khas dan kadangkadang didominasi oleh latar belakang budaya, (d) sebagian besar pelajar BIPA memiliki minat, dan motivasi yang tinggi terhadap bahasa Indonesia, (e) para pelajar BIPA memiliki latar belakang keilmuan yang berbeda-beda, dan (f) karena perbedaan sistem bahasa, pelajar BIPA banyak menghadapi kesulitan terutama dalam masalah pelafalan dan penulisan (Suyitno, 2007).

Pebelajar BIPA adalah pebelajar yang telah memiliki bahasa pertama dan memiliki latar belakang budaya yang berbeda. Perbedaan itu tentu akan berdampak pada materi pelajaran yang akan diajarkan. Prasetyo (2016) menyatakan setiap pebelajar yang akan belajar bahasa Indonesia melalui sebuah lembaga bahasa, akan mengisi formulir analisis kebutuhan yang telah disediakan oleh lembaga bahasa. Tujuannya adalah untuk memudahkan pengajar dalam menyusun bahan ajar dan media pembelajaran yang akan diterapkan saat proses pembelajaran berlangsung dan agar sesuai dengan tujuan belajar bahasa Indonesia.

Di dalam proses pembelajaran tentu ada beberapa masalah yang muncul, yang membuat peserta didik tidak dapat secara maksimal menyerap ilmu yang disampaikan oleh pengajar. Permasalahan yang paling sering dialami saat proses pembelajaran adalah kelas yang monoton, penggunaan metode dan teknik mengajar yang monoton, tidak adanya bahan ajar bahkan tidak digunakan media pembelajaran juga bisa berdampak buruk terhadap motivasi belajar siswa di kelas.

Menurut wawancara dengan salah satu pengajar BIPA di UPT Bahasa Undiksha, masalah-masalah pembelajaran seperti itu juga masih sering muncul dalam pembelajaran BIPA di Undiksha. Penggunaan metode langsung, metode terjemahan tata bahasa, metode audio lingual seringkali membuat siswa BIPA merasa bosan saat belajar di kelas. Tetapi, pengajar BIPA cepat tanggap terhadap situasi yang seperti itu dan menanggulanginya dengan mengajak siswa belajar di luar kelas dan menerapkan metode eclectic (Metode Campuran). Metode eclectic atau Eclectic Aproach adalah suatu tujuan dengan memilih hal yang paling sesuai dengan kebutuhan dan mengambil dari berbagai sumber yang berkaitan (Budiningtyas, 2010). Permasalahan pada tidak adanya bahan ajar sudah ditanggulangi pula oleh UPT Bahasa Undiksha dengan mengajak pengajar BIPA untuk menyusun buku ajar BIPA. Akan tetapi, permasalahan mengenai media pembelajaran saaat ini belum bisa diatasi. Adapun permasalahan yang dimaksud adalah, saat ini buku ajar "Selamat Datang" yang dimiliki oleh UPT Bahasa Undiksha belum dilengkapi dengan media pembelajaran yang mendukung proses pembelajaran BIPA. Padahal, penggunaan media pembelajaran sangat penting dalam proses belajar mengajar.

Media berfungsi untuk tujuan instruksi ketika informasi yang terdapat dalam media itu harus melibatkan siswa baik dalam benak atau mental maupun dalam bentuk aktivitas yang nyata sehingga pembelajaran dapat terjadi (Arsyad, 2016:25). Adapun peran penting media pembelajaran dalam proses belajar mengajar adalah (1) penyampaian pelajaran menjadi lebih baku, (2) pembelajaran bisa lebih menarik, (3) pembelajaran menjadi lebih interaktif, (4) lama waktu pembelajaran yang diperlukan 
dapat dipersingkat karena kebanyakan media hanya memerlukan waktu singkat untuk mengantarkan isi pelajaran, (5) kualitas hasil belajar dapat ditingkatkan bilamana integrasi kata dan gambar sebagai media pembelajaran dapat mengkomunikasikan elemen-elemen pengetahuan dengan cara yang terorganisasikan dengan baik, spesifik, dan jelas, (6) pembelajaran dapat diberikan kapan dan di mana diinginkan atau diperlukan terutama jika media pembelajaran dirancang untuk penggunaan secara individu, (7) sikap positif siswa terhadap apa yang mereka pelajari dan terhadap proses belajar dapat ditingkatkan, (8) peran guru dapat berubah ke arah yang lebih positif, guru sebagai konsultan atau penasihat siswa (Arsyad, 2016:25-27).

Media pembelajaran dalam pembelajaran BIPA dapat memudahkan pengajar untuk mengajarkan bahasa Indonesia kepada penutur asing. Penutur asing pun dapat memahami materi yang dipelajari dengan mudah. Pemilihan media pembelajaran dapat disesuaikan dengan kebutuhan pebelajar. Oleh karena itu, pengajar dituntut untuk berinovasi terutama dalam hal pengembangan pembelajaran melalui media pembelajaran yang kreatif dan inovatif.

Pemilihan tempat di UPT Bahasa Undiksha yang dipergunakan sebagai tempat penelitian, karena di UPT Bahasa Undiksha terdapat permasalahan mengenai media pembelajaran yang kurang lengkap untuk menunjang proses pembelajaran BIPA. Dari hasil wawancara dengan salah satu pengajar di UPT Bahasa Undiksha dapat disimpulkan bahwa adanya kekurangan media berdasarkan buku BIPA Pemula yang digunakan untuk proses pembelajaran. Peran media dalam proses pembelajaran di kelas sangat penting karena bisa membantu memberikan pemahaman dan untuk pengajar sangat membantu dalam menyampaikan materi. Selain itu, media pembelajaran berbasis visual belum digunakan secara maksimal dalam proses pembelajaran di UPT Bahasa Undiksha.
Di dalam buku ajar "Selamat Datang" yang dimiliki oleh UPT Bahasa terdapat beberapa unit yang harus dipelajari oleh mahasiswa BIPA selama kurang lebih empat bulan lamanya. Dari sekian unit, ada beberapa yang belum terdapat media pembelajaran. Ketersediaan media pembelajaran yang belum lengkap sesuai dengan konten buku ajar "Selamat Datang" menyebabkan adanya perbedaan persepsi atau penyampaian pesan tentang sesuatu antara pengajar dengan pebelajar BIPA. Penyampaian pesan tentang sesuatu kepada pebelajar bahasa Indonesia pemula, tidak cukup hanya dengan penjelasan guru dan buku ajar saja.

Penelitian sejenis tentang BIPA pernah dilakukan oleh Ni Putu Apita Widya Sari. Penelitian yang berjudul Pembelajaran Bahasa Indonesia Bagi Penutur Asing di Sekolah Cinta Bahasa, Ubud ini menggunakan rancangan penelitian deskriptif kualitatif dan metode pengumpulan data yang digunakan adalah metode observasi, dokumentasi dan wawancara. Instrumen pengumpulan data yang digunakan adalah catatan lapangan, catatan dokumen dan pedoman wawancara. Adapun subjek penelitian ini adalah pengajar BIPA di Sekolah Cinta Bahasa, dan objek penelitiannya adalah perencanaan, pelaksanaan, dan evaluasi pembelajaran BIPA serta alasan guru memilih prosedur tertentu dalam pembelajaran BIPA. Yang kedua adalah penelitian yang dilakukan oleh Yuniarti Rahmalia Hapsari dengan judul Pelaksanaan Pembelajaran Berbicara BIPA Siswa Kelas IX Di Gandhi Memorial Intercontinental School Bali. Penelitian ini memiliki persamaan dengan penelitian yang sebelumnya dari segi rancangan penelitian. Namun, subjek dan objek yang digunakan berbeda. Adapun subjek dari penelitian ini adalah pengajar siswa kelas IX di Gandhi Memorial Intercontinental School Bali, dan objeknya adalah perencanaan, pelaksanaan, dan evaluasi pembelajaran BIPA di kelas IX GMIS Bali.

Penelitian sejenis yang ketiga dilakukan oleh I Made Arta Yasa, dengan judul penelitian adalah Pelaksanaan 
Pembelajaran Dengan Menggunakan Metode Praktik Langsung Untuk Siswa BIPA Beginner Class di Yayasan Cinta Bahasa Indonesian Language School. Rancangan penelitian yang digunakan sama dengan penelitian sejenis yang telah dipaparkan. Adapun objek penelitian ini adalah perencanaan, pelaksanaan, dan evaluasi pembelajaran menggunakan metode praktik langsung untuk siswa BIPA Beginner Class. Subjek dalam penelitian ini adalah pengajar BIPA dan siswa BIPA Beginner Class di Yayasan Cinta Bahasa Indonesian Language School. Terakhir, penelitian sejenis yang dilakukan oleh I Putu Andika Subagya Putra berjudul Film Seri Animasi 3D "Belajar Bahasa Indonesia Bersama Made" Sebagai Media Pembelajaran Bahasa Indonesia Untuk Penutur Asing di Undiksha. Rancangan penelitian ini berbeda dari penelitian sejenis lainnya. Rancangan penelitian yang digunakan adalah Research and Development (RnD) dengan menggunakan model pengembangan ADDIE. Adapun subjek dari penelitian ini adalah siswa BIPA yang belajar di UPT Bahasa Undiksha. Sedangkan objek penelitian ini adalah media pembelajaran yang digunakan di UPT Bahasa Undiksha. Tujuan dari penelitian ini adalah untuk mengembangkan Film Seri Animasi 3D sebagai media pembelajaran bahasa Indonesia bagi penutur asing, agar mahasiswa asing yang tinggal dan atau berkunjung ke Indonesia dengan mudah dapat mempelajari bahasa Indonesia.

Berdasarkan keempat penelitian sejenis tersebut, hanya satu yang juga meneliti dan mengembangkan media pembelajaran. Bedanya penelitian tersebut mengembangkan media pembelajaran audio visual berupa video animasi 3D. Oleh sebab itu, penelitian media pembelajaran visual berupa flashcard ini penting untuk dikembangkan.

Penelitian dan pengembangan ini diharapkan dapat menghasilkan produk media pembelajaran BIPA khusus untuk pebelajar tingkat pemula yang sesuai dengan buku ajar dan kebutuhan belajar siswa BIPA. Diharapkan juga adanya peningkatan motivasi keberhasilan belajar dengan menggunakan media. Oleh karena itu, penulis mencoba mengembangkan media pembelajaran yang inovatif dengan memanfaatkan media Flashcard sebagai media pembelajaran yang sesuai dengan konten buku BIPA "Selamat Datang". Peneliti memilih mengembangkan media pembelajaran Flashcard karena beberapa alasan. Pertama, media flashcard mudah dibawa kemana-mana. Kedua, cara membuat dan menggunakan media flashcard sangat praktis, sehingga kapanpun guru dan siswa BIPA bisa belajar dengan baik menggunakan media ini. Ketiga, gampang diingat karena flashcard berbentuk kartu bergambar yang sangat menarik perhatian, berisi huruf atau angka yang sederhana dan menarik, sehingga dapat merangsang otak untuk lebih lama mengingat pesan yang ada pada kartu tersebut. Peneliti memilih mengembangkan media pembelajaran BIPA tingkat pemula, karena pebelajar BIPA sulit memahami materi-materi yang terdapat di dalam buku panduan BIPA menggunakan bahasa Indonesia. Media pembelajaran flashcard ini sangat cocok diterapkan untuk beberapa unit yang terdapat di dalam buku ajar BIPA "Selamat Datang" yaitu, unit 1 salam, unit 3 angka, dan unit 6 anggota tubuh. Penggunaan media flashcard dianggap membantu pebelajar untuk memahami konten yang terdapat di buku dan mampu menerapkannya menggunakan bahasa Indonesia.

Berdasarkan pemaparan masalah tersebut, penelitian ini mengkaji tentang, 1) bagaimana media pembelajaran visual bagi pebelajar BIPA pemula di Undiksha, 2) bagaimana validitas hasil pengembangan media pembelajaran visual bagi pebelajar BIPA pemula di Undiksha, 3) bagaimana respon pebelajar BIPA pemula terhadap media yang digunakan?

Sejalan dengan rumusan masalah di atas, maka tujuan dari penelitian ini adalah 1) menjabarkan desain pengembangan media pembelajaran visual bagi pebelajar BIPA pemula di Undiksha, 2) menguji validitas hasil pengembangan media pembelajaran visual bagi pebelajar BIPA 
pemula di Undiksha, 3) mengetahui respon pebelajar BIPA terhadap media pembelajaran yang digunakan.

\section{METODE PENELITIAN}

\section{A. Rancangan Penelitian}

Rancangan penelitian yang digunakan dalam penelitian ini adalah Research and Development $(\mathrm{RnD})$. Jenis penelitian yang dilaksanakan adalah Penelitian dan Pengembangan dengan menggunakan model ADDIE. Research and Development adalah metode penelitian yang digunakan untuk menghasilkan suatu produk tertentu dan menguji keefektifan produk tersebut.

Mulyatiningsih (dalam Andika, 2017) menyatakan bahwa model pengembangan ADDIE merupakan singkatan dari Analysis, Design, Development, Implementation, and Evaluation. Secara visual tahapan model ADDIE dapat dilihat seperti gambar berikut ini:

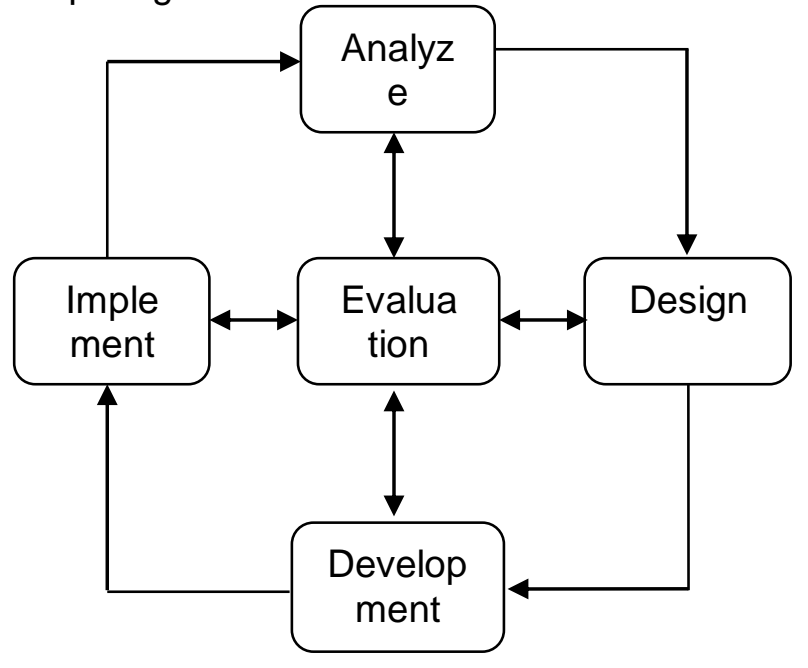

Sumber: Anglada (dalam Tegeh, dkk 2014: 42)

Adapun tahapan model ADDIE adalah sebagai berikut.

\section{1) Analyze (Analisis)}

Pada tahapan ini ada beberapa kegiatan yang dilakukan yaitu, analisis kurikulum, analisis karakteristik peserta didik, analisis sumber belajar, serta analisis kebutuhan. Secara rinci dapat dijelaskan sebagai berikut.

- Analisis Kurikulum
Berdasarkan hasil analisis silabus, maka dapat dirumuskan indikator pencapaian yang ingin dicapai melalui media yang dikembangkan. Indikator tersebut dapat dilihat pada tabel 1.

Tabel 1.Indikator Pencapaian

\begin{tabular}{|l|l|l|}
\hline No & Topik Materi & $\begin{array}{l}\text { Indikator } \\
\text { Pencapaian }\end{array}$ \\
\hline 1. & Salam & $\begin{array}{l}\text { Mengucapkan } \\
\text { salam, dan kata } \\
\text { ganti orang }\end{array}$ \\
\hline 2. & Angka & $\begin{array}{l}\text { Mengucapkan } \\
\text { jumlah barang }\end{array}$ \\
\hline 3. & $\begin{array}{l}\text { Anggota } \\
\text { tubuh }\end{array}$ & $\begin{array}{l}\text { Mengucapkan } \\
\text { nama anggota } \\
\text { tubuh }\end{array}$ \\
\hline
\end{tabular}

- Analisis Karakter Peserta Didik

Analisis peserta didik BIPA dilakukan untuk mengetahui tujuan belajar, kebiasaan, dan sikap sehari-hari siswa yang digunakan pegangan dan acuan dalam pengembangan media flashcard ini.

- Analisis Sumber Belajar

Analisis sumber belajar merupakan kegiatan yang dilakukan untuk mengetahui sumber, media, metode pembelajaran, dan cara guru menyampaikan materi agar peserta didik tertarik untuk belajar. Sumber belajar yang digunakan adalah buku ajar BIPA pemula yang berjudul "Selamat Datang".

- Analisis Kebutuhan

Langkah analisis kebutuhan diperlukan untuk menentukan kemampuan atau kompetensi yang perlu dipelajari oleh peserta didik BIPA pemula, dengan melihat berbagai permasalahan, sehingga ditawarkan solusi dengan pengembangan media flashcard.

\section{2) Design (Perancangan)}

Memasuki tahap design/perancangan ini, peneliti membuat sketsa yang menggambarkan suatu elemen-elemen yang terdapat pada media flashcard. Proses pengerjaan media flashcard ini 
dibuat dengan menggunakan aplikasi Adobe Photoshop Cs6.

\section{3) Development (Pengembangan)}

Berdasarkan tahap perancangan sebelumnya, tahap pengembangan media flashcard ini melewati 6 tahapan pengeditan. Adapun keenam tahap tersebut, yaitu: tahap new layer, tahap insert picture, tahap insert text, tahap pewarnaan text, tahap pembuatan sisi belakang flashcard, dan tahap penyimpanan.

4) Implement (Implementasi)

Pada tahap ini kegiatan yang dilakukan yaitu hasil pengembangan yang dibuat kemudian diterapkan dalam kegiatan pembelajaran BIPA tingkat pemula di Undiksha, untuk mengetahui respon siswa BIPA terhadap media flashcard yang dikembangkan

\section{5) Evaluation (Evaluasi)}

Pada tahap evaluasi dilakukan penelitian media berdasarkan evaluasi formatif. Evaluasi formatif dilakukan untuk memperbaiki produk yang dihasilkan dengan uji coba lapangan dan berdasarkan respon siswa BIPA.

B. Instrumen Pengumpulan Data

Pada penelitian pengembangan ini, metode yang digunakan untuk mengumpulkan data adalah metode pencatatan dokumen, wawancara, dan angket. Instrumen yang digunakan untuk mengumpulkan data dalam penelitian ini adalah kuesioner. Instrumen kuesioner digunakan pada tahap validasi yang meliputi uji coba ahli dan uji coba lapangan. Kuesioner digunakan untuk mengumpulkan data hasil review dari ahli media pembelajaran.

C. Teknik Analisis dan Validasi Data Penelitian pengembangan ini menggunakan dua teknik analisis data, yaitu teknik analisis deskriptif kuantitatif, dan teknik analisis deskriptif kualitatif.

- Analisis Deskriptif Kuantitatif
Analisis deskriptif kuantitatif digunakan untuk menyajikan data hasil penelitian berupa angka. Metode analisis statistik ini dilakukan dengan cara menerapkan rumus statistik deskriptif seperti: distribusi frekuensi, grafik, angka rata-rata, median, modus, mean, dan standar deviasi untuk menggambarkan objek/variabel tertentu sehingga diperoleh kesimpulan umum. Rumus yang digunakan untuk menghitung persentase dari masing-masing subjek menurut Tegeh (dalam Prasetya, 2015)

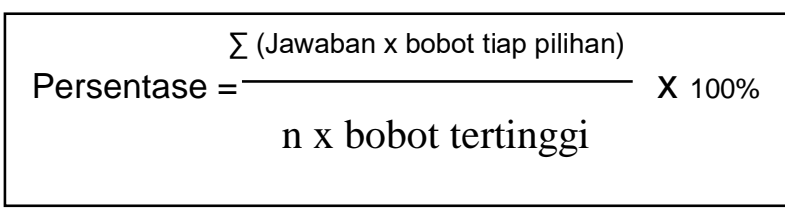

Tabel 2. Konversi PAP Tingkat Pencapaian dengan Skala 5

\begin{tabular}{|l|l|}
\hline $\begin{array}{l}\text { Tingkat Pencapaian } \\
(\%)\end{array}$ & Kualifikasi \\
\hline $90-100$ & Sangat baik \\
\hline $80-89$ & Baik \\
\hline $65-79$ & Cukup \\
\hline $55-64$ & Kurang \\
\hline $0-54$ & Sangat kurang \\
\hline
\end{tabular}

Sumber: Agung (dalam Febriani, 2015)

Setelah menghitung persentase tingkat pencapaian, maka hasilnya harus dikonversikan kedalam tabel konversi untuk mengetahui apa kualifikasi yang cocok media flashcard ini. Berdasarkan rumus tersebut, persentase tingkat pencapaian masing-masing unit adalah sebagai berikut.

1. Unit 1

$$
\frac{48}{(10 \times 5)} \times 100 \%=96 \% \text {. }
$$

2. Unit 3

$$
\frac{40}{(10 \times 5)} \times 100 \%=80 \% \text {. }
$$

3. Unit 6 


$$
\frac{37}{(10 x 4)} \times 100 \%=92,5 \% \text {. }
$$

Perhitungan nilai rata-rata respon siswa dapat dihitung dengan rumus:

$\bar{X}=\frac{\sum x}{N}=\frac{1221}{19}=64,26$

Keterangan:

$\bar{x}=$ rata-rata untuk skor respon peserta didik

$\sum \mathrm{x}=$ jumlah skor respon peserta didik

$\mathrm{N}$ = banyak peserta didik

Sedangkan untuk mencari mean ideal (MI) dan standar derivasi ideal (SDI) dapat dilakukan dengan menggunakan rumus berikut.

$\mathrm{Mi}=\frac{1}{2}$ (skor maksimal ideal + skor terendah ideal)

$M i=\frac{1}{2}(75+15)=45$

$\mathrm{SDi}=\frac{1}{6} \underset{\text { terendah ideal })}{\text { (skor tertinggi ideal }}+$ skor

$S D i=\frac{1}{6}(75+15)=15$

Keterangan:

Smax = skor maksimum ideal, yaitu skor tertinggi yang mungkin dicapai

Smin = skor minimum ideal, yaitu skor terendah yang mungkin dicapai

Rata-rata kelas $(\bar{x})$ dari skor respon siswa kemudian dikategorikan dengan menggunakan pedoman seperti tabel 2

Tabel 3. Kriteria Penggolongan Respon Peserta Didik

\begin{tabular}{|l|l|l|}
\hline No & Interval & Kategori \\
\hline 1 & $X \geq 72$ & Sangat positif \\
\hline 2 & $72>X \geq 36$ & Positif \\
\hline 3 & $54>X \geq 36$ & Kurang positif \\
\hline 4 & $36>X \geq 18$ & Negatif \\
\hline
\end{tabular}

\begin{tabular}{|l|l|l|}
\hline 5 & $x<18$ & Sangat negatif \\
\hline
\end{tabular}

- Analisis Deskriptif Kualitatif

Teknik analisis deskriptif kualitatif ini digunakan untuk mengolah data hasil review ahli media pembelajaran dan uji coba lapangan yang disajikan menggunakan analisis deskriptif kualitatif adalah data yang tidak berbentuk angka. Teknik analisis ini digunakan untuk menyajikan dan menganalisis data yang diperoleh dari kuesioner terbuka berupa komentar dan saran terhadap produk media pembelajaran flashcard. Hasil analisis kemudian digunakan untuk merevisi produk pengembangan.

\section{HASIL DAN PEMBAHASAN}

\section{Desain Pengembangan Media Pembelajaran Visual Bagi Pebelajar BIPA Pemula di Undiksha}

Desain media flashcard dibuat dengan menggunakan aplikasi Adobe Photoshop Cs6 karena aplikasi ini lebih mudah dipelajari dan memiliki fitur-fitur yang lebih banyak. Pada desain media flashcard digunakan huruf jenis Comic Sans Ms karena huruf ini mudah dibaca. Media flashcard didesain dengan ukuran huruf lebih dari 72 points. Ukuran huruf yang kurang dari 72 points sulit untuk dibaca saat pengguna menggunakan media flashcard. Pemilihan latar belakang (background) yang tidak terlalu mencolok, agar memperjelas tulisan dan gambar pada flashcard. Desain media flashcard haruslah sesederhana mungkin dan tidak terlalu menonjolkan efek warna saja dan harus tetap memperhatikan prinsip-prinsip pembuatan media pembelajaran, yaitu prinsip kesederhanaan, kesesuaian tulisan dengan gambar, keterpaduan warna, dan lain-lain. Hal tersebut sejalan dengan pendapat (Arsyad, 2016:89) menyatakan ada beberapa prinsip umum yang perlu diketahui untuk penggunaan efektif media berbasis visual sebagai berikut. 1) usahakan visual itu sesederhana mungkin dengan menggunakan gambar garis, karton, bagan, dan diagram, 2) unsur- 
unsur pesan dalam visual itu harus ditonjolkan dan dengan mudah dibedakan dari unsur-unsur latar belakang untuk mempermudah pengolahan informasi, 3) visual digunakan untuk menekankan informasi sasaran (yang terdapat teks) sehingga pembelajaran dapat terlaksana dengan baik, dan 4) gunakan gambar untuk melukiskan perbedaan konsepkonsep misalnya dengan menampilkan konsep-konsep yang divisualkan itu secara berdampingan.

Media pembelajaran flashcard ini dibuat menggunakan kertas karton tebal berukuran 25×30 $\mathrm{cm}$ dan memiliki dua sisi yang berbeda. Pada sisi pertama terdapat gambar dengan kosakata berbahasa Indonesia, sedangkan sisi kedua berisi kosakata berbahasa Inggris. Tujuan dicantumkannya dua sisi tersebut, untuk memudahkan siswa BIPA memahami kosakata bahasa Indonesia.

Desain media flashcard tersebut dikembangkan sehingga menghasilkan media pembelajaran yang sesuai dengan tingkat kebutuhan dan kompetensi yang diharapkan. Komponen media pembelajaran disusun secara sistematis, dirancang dalam bentuk yang menarik, sehingga pada akhirnya media flashcard untuk pebelajar BIPA pemula ini mampu meningkatkan pemahaman siswa BIPA.

\section{Validitas Hasil Pengembangan Media Pembelajaran Visual Bagi Pebelajar BIPA Pemula di Undiksha}

Uji coba produk kepada ahli media pembelajaran ditujukan untuk mengetahui kelayakan produk, dilihat dari segi media pembelajaran. Persentase tingkat pencapaian dari ahli media pembelajaran untuk media flashcard memperoleh hasil yang berbeda-beda pada setiap unit. Unit 1 memeroleh hasil sebesar 96\% dengan kualifikasi sangat baik, unit 3 memperoleh tingkat pencapaian $80 \%$ dengan kualifikasi baik, dan unit 6 memperoleh bobot 92,5\% dengan kualifikasi sangat baik. Berdasarkan hasil tersebut, media pembelajaran yang dikembangkan sekurang-kurangnya memperoleh kualifikasi baik.
Adapun hasil analisis berdasarkan penilaian ahli media, yaitu berikut ini. (1) Mengacu pada unsur keterpaduan, beberapa media flashcard pada unit 1 dan unit 6 masih menimbulkan kerancuan makna antara gambar dan tulisan. Adapun unsur keterpaduan yang dimaksud oleh Arsyad (2016) yaitu, keterpaduan mengacu kepada hubungan yang terdapat di antara elemen-elemen visual yang ketika diamati akan berfungsi secara bersama-sama. (2) Sesuai dengan prinsip keseimbangan, media flashcard belum memenuhi kriteria keseimbangan pola dan bentuk gambar yang dipilih. Untuk dapat memenuhi kriteria keseimbangan ini Arsyad (2016) menyatakan bahwa pengembangan visual dengan keseimbangan informal memerlukan daya imajinasi yang lebih tinggi dan keinginan bereksperimen dari perancang visual. (3) Keefektifan media flashcard dalam pembelajaran perlu diperbaiki kembali, mengingat ukuran flashcard yang berukuran $25 \times 30 \mathrm{~cm}$ tidak cocok digunakan untuk kelas yang jumlah siswa banyak. Penggunaan flashcard agar lebih efektif, bisa disiasati dengan cara membentuk kelompok kecil yang bisa mengamati tampilan visual flashcard dengan jelas.

Temuan tersebut sejalan dengan pendapat Daryanto (2016:39) yang mengungkapkan bahwa media visual memerlukan pengamatan yang ekstra hati-hati. Selain itu, media visual memuat pesan atau informasi yang panjang atau rumit, sehingga mengharuskan untuk membagi ke dalam beberapa bahan visual yang mudah dibaca dan mudah dipahami. (4) Kemenarikan tampilan fisik media flashcard dapat membantu siswa meningkatkan rasa ingin tahu siswa untuk mempelajari hal baru, misalnya mempelajari kosakata bahasa Indonesia bagi pebelajar BIPA pemula. Temuan tersebut sejalan dengan pendapat Daryanto (2016:39) menyatakan bahwa media visual membantu siswa meningkatkan pemahaman dan memperkuat ingatan, sebab tampilan visual lebih menarik daripada tampilan verbal. (5) Gambar-gambar yang terdapat 
di dalam media flashcard adalah gambar yang bisa ditemukan sehari-hari, sehingga memudahkan pebelajar BIPA pemula untuk memahami hal-hal yang baru dipelajari. Hal tersebut sejalan dengan pendapat Daryanto (2016) mengenai kelebihan media visual yang dapat membantu menanamkan konsep yang benar mengenai suatu informasi dan memungkinkan adanya interaksi antara siswa dengan lingkungan sekitarnya. (6) Flashcard dapat menambah perbendaharaan kosakata terutama kosakata bahasa asing. Temuan ini sejalan dengan tujuan pembelajaran BIPA yang disampaikan oleh Suyitno (2007) bahwa tujuan yang hendak dicapai ialah mempermudah pelajar menguasai bahasa Indonesia. Hasil penilaian ahli media mengindikasikan bahwa produk berupa media pembelajaran yang dikembangkan layak untuk digunakan dalam pembelajaran BIPA.

\section{Respon Pebelajar BIPA Pemula terhadap Media Flashcard}

Secara keseluruhan respon siswa mendapat hasil yang positif. Nilai rerata respon siswa yang didapat adalah sebesar 64,26 dengan tingkat persentase mencapai $85,65 \%$. Hasil tersebut menunjukkan bahwa siswa memiliki ketertarikan yang besar terhadap media visual dua dimensi, senang saat belajar dengan menggunakan media flashcard, semakin bersemangat belajar, mudah mengucapkan kembali kosakata yang ada pada media, dan mampu mengikuti kegiatan pembelajaran BIPA dengan media flashcard. Meskipun demikian, masih ada beberapa siswa yang menilai bahwa media pembelajaran flashcard kurang efektif diterapkan, hal ini terjadi karena gambar kurang menarik, tulisan yang terlalu kecil sehingga sulit dibaca, warna latar belakang yang terlalu kontras, dan ukuran flashcard yang ukurannya tidak terlalu besar.

Secara keseluruhan pelaksanaan pembelajaran dengan menggunakan media pembelajaran flashcard sudah berjalan dengan baik. Pebelajar BIPA merasa senang belajar menggunakan media flashcard dalam proses pembelajaran. Hal tersebut sejalan dengan tujuan pengajaran BIPA menurut Depdikbud (dalam Prasetyo, 2016) adalah supaya pebelajar mampu berkomunikasi dengan menggunakan bahasa Indonesia secara baik dan benar, baik secara lisan maupun tertulis, yang meliputi empat keterampilan. Keempat keterampilan yang dimaksud adalah berbicara, menyimak, membaca, dan menulis.

\section{SIMPULAN DAN SARAN}

Berdasarkan paparan pada bagian hasil penelitian dan pembahasan, dapat ditarik simpulan sebagai berikut. Pertama, pengembangan media flashcard sebagai media pembelajaran bahasa Indonesia bagi penutur asing pemula di Undiksha sudah berhasil dilakukan sesuai rancangan yang disusun dengan menggunakan model ADDIE. Media flashcard ini memiliki 2 sisi yang berbeda, pada sisi pertama terdapat gambar dengan kosakata bahasa Indonesia, sedangkan sisi kedua menggunakan kosakata bahasa Inggris. Penambahan kosakata bahasa Inggris dilakukan agar memudahkan pebelajar BIPA pemula untuk menguasai kosakata berbahasa Indonesia. Pengerjaan media flashcard ini menggunakan software Adobe Photoshop Cs6.

Kedua, hasil validitas ahli media menunjukkan hasil yang berbeda-beda pada setiap unit yang dipilih. Unit 1 mendapatkan hasil $96 \%$ berada pada kualifikasi sangat baik, unit 3 mendapatkan hasil $80 \%$ dengan kualifikasi baik, dan unit 6 mendapatkan hasil 92,5\%. Secara keseluruhan media flashcard mendapat beberapa saran dan masukan yang berguna untuk penyempurnaan tampilan dan cara penggunaannya. Berdasarkan hasil penilaian ahli media pembelajaran, media flashcard ini sesuai dengan rancangan yang telah disusun dan layak untuk dilanjutkan.

Ketiga, pengembangan media flashcard ini mendapat respon positif dari siswa BIPA Undiksha dengan rata-rata skor siswa sebesar 64,26 dan bila 
dikonversikan mendapat rata-rata persentase sebesar $85,68 \%$.

Berdasarkan hasil penelitian pengembangan dan simpulan, saran yang dapat diberikan kepada pembaca untuk pengembangan selanjutnya adalah sebagai berikut. 1) Pengembangan media pembelajaran flashcard ini layak digunakan dalam proses pembelajaran BIPA tingkat pemula, karena hasil validitras ahli menyatakan media pembelajaran ini valid dan mendapatkan respon positif dari siswa BIPA tingkat pemula di Undiksha. 2) Peneliti lain disarankan untuk melakukan penelitian sejenis terkait dengan media pembelajaran BIPA. Penelitian ini menggunakan metode Penelitian dan Pengembangan (Research and Development) dengan memilih model penelitian ADDIE. Oleh sebab itu, disarankan bagi peneliti lain untuk melakukan penelitian dengan menggunakan metode yang sama dan mengembangkan media pembelajaran BIPA tingkat lanjut.

\section{DAFTAR PUSTAKA}

Arsyad, Azhar. 2016. Media Pembelajaran. Jakarta: PT Raja Grafindo Persada

Budiningtyas, Niken. 2010. Penerapan Pendekatan Eclectic dalam Pembelajaran PPKN (Studi Kasus di SMP N 7 Surakarta). Skripsi (tidak diterbitkan). Surakarta: Universitas Sebelas Maret

Candiasa, I Made. 2011. Pengujian Instrumen Penelitian Disertai Aplikasi ITEMAN dan BIGSTEPS. Unit Penerbitan Undiksha: Singaraja

Daryanto. 2013. Media Pembelajaran Perananannya Sangat Penting Dalam Mencapai Tujuan Pembelajaran. Yogyakarta: Gava Media

Febriani, Luh Putu Ayu. 2015. Pengembangan Video Pembelajaran Dengan Model ADDIE Pada Mata Pelajaran Bahasa Indonesia Kelas $X$ Semester Genap Tahun Pelajaran 2014/2015 Di SMK Negeri 3
Singaraja. Skripsi (tidak diterbitkan). Singaraja: Universitas Pendidikan Ganesha

Hapsari, Yuniarti Rahmalia. 2017. Pelaksanaan Pembelajaran Berbicara BIPA Siswa Kelas $X$ di Gandhi Memorial International School Bali. Skripsi (tidak diterbitkan). Singaraja: Undiksha

Muliastuti, Liliana. 2016. BIPA Pendukung Internasionalisasi Bahasa Indonesia.E-Journal Untidar tersedia pada http://fkip.untidar.ac.id/wpcontent/uploads/2016/10/Liliana-

Muliastuti-BIPA-PendukungInternasionalisasi-BahasaIndonesia.pdf

Prastya, I Gede Hendra. Pengembangan Multimedia Pembelajaran Interaktif Mata Pelajaran Bahasa Indonesia Dengan Model ADDIE Untuk Siswa Kelas VII Semester Genap Tahun Pelajaran 2014-2015 Di SMP Negeri 1 Banjar. Skripsi (tidak diterbitkan). Singaraja: Universitas Pendidikan Ganesha.

Putra, I Putu Subagya Andika. 2017. Film Seri Animasi 3D "Belajar Bersama Made" Sebagai Media Pembelajaran Bahasa Indonesia Untuk Penutur Asing di Undiksha. Singaraja: Undiksha

Suyitno, Imam. 2007. Pengembangan Bahan Ajar Bahasa Indonesia untuk Penutur Asing (BIPA) Berdasarkan Hasil Analisis Kebutuhan Belajar. Ejournal UI tersedia pada http://journal.ui.ac.id/index.php/waca na/article/view/3677/2930

Tegeh, I Made, dkk. 2014. Model Penelitian Pengembangan. Yogyakarta: Graha IImu

Wirawan, Adica. 2016. Peluang Bahasa Indonesia Menjadi Bahasa Utama Asean. E-Journal tersedia pada http://www.kompasiana.com/adica.wi rawan/peluang-bahasa-indonesiamenjadi-bahasa-utama-asean 